\title{
Photoelectrochemical Deposition of CdZnSe Thin Films on the Se-Modified Au Electrode
}

\author{
Sunyoung Ham, Soyeon Jeon, Ungki Lee, ${ }^{\dagger}$ Ki-Jung Paeng, and Noseung Myungł‘`

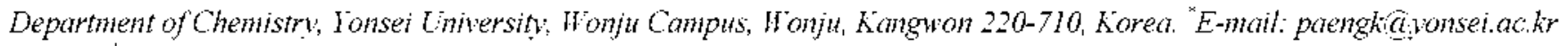 \\ ${ }^{\dagger}$ Department of Applied Chemistry, Konhatk Lniversity, Chungin Campus, Chungju, Chungbuk 380-701, Korea \\ ${ }^{*}$ E-mail: mutung akku.ack kr \\ Received January 25, 2008
}

\begin{abstract}
Photoelectrochemical deposition of CdZnSe thin films on the Se-modified Au electrode using electrochemical quartz crystal microgravimetry (EQCM) and voltammetry is described. Corrosion of pre-deposited Se electrodes by illumination at a fixed potential resulted in $\mathrm{Se}^{-2}$ species. which was manifest from the EQCM frequency changes. $\mathrm{Se}^{2-}$ species generated from the photocorrosion reacted with $\mathrm{Cd}^{2+}$ and $\mathrm{Zn}^{2+}$ ions in the electrolyte to form $\mathrm{CdZnSe}$ films on the Au electrode. The effect of electrolyte composition on the composition and band gap of $\mathrm{CdZnSe}$ films was stıdied in detail. Also. photoelectrochemistry. EDX. Raman spectroscopy were used for the characterization of $\mathrm{CdZnSe}$ thin films.
\end{abstract}

Key Words : Photoelectrochemistry. CdZnSe. Temary senuiconductor. EQCM

\section{Introduction}

Group 12-16 compound semiconductors are important in a wide spectrum of optoelectronic applications. ${ }^{.}$Especially. ternary compounds including cadmium zinc selenide ( $\mathrm{CdZnSe}$ ) have attracted much attention in the fields of solar cells due to their interesting properties of band gap modulation by composition ${ }^{-6}$ For example band gap values of $\mathrm{CdZnSe}$ ternary semiconductors can be varied from $1.7 \mathrm{eV}$ (CdSe) to $2.7 \mathrm{eV}(\mathrm{ZnSe})$ with composition. $=-4$

Different methods have been used for the synthesis of ternary compounds including vacuum techniques. chemical bath deposition and electrodeposition. ${ }^{1-6}$ In particular. electrodeposition is a simple and cost-effective approach. which can conveniently modulate the composition of the thin films using electrolyte composition and deposition potentials. ${ }^{1}$

Photocorrosion reaction is detrimental to the long-term stability of the photoelectrode and can be prevented by a suitable redox couple. ${ }^{7}$ As an extension to the previous studies ${ }^{8.9}$ we utilized photocorrosion reaction to synthesize ternary semiconductor $\mathrm{CdZnSe}$ thin films. Photoexcitation of the pre-deposited p-Se generates $\mathrm{Se}^{2-}$ under light illumination and thus generated $\mathrm{Se}^{2-}$ species react with $\mathrm{Cd}^{2-}$ and $\mathrm{Zn}^{--}$in electrolyte to result in $\mathrm{CdZnSe}$. The composition as well as band gap of the film varies with electrolyte composition. This approach is validated using electrochemical quartz crystal microgravimetry (EQCM) and voltammetry.

\section{Experimental}

Details of the electrochemical instrumentation and the set-up for electrochemical quartz crystal microgravimetry (EQCM) are given elsewhere ${ }^{8.9}$ For voltanmetry and film deposition an EG\&G Princeton Applied Research (PAR) 263A instrument equipped with Model M250/270 electro- chenistry software was used. For EQCM. a Seiko EG\&G Model QCA 917 instrument consisting of an oscillator module (QCA 917) and a $9 \mathrm{MHz}$ AT-cut gold-coated quartz crystal (geometric area. $0.2 \mathrm{~cm}^{2}$ ) as a working electrode were used. A Pt wire served as a counter electrode and the reference electrode was $\mathrm{Ag} / \mathrm{AgCl} / 3 \mathrm{M} \mathrm{NaCl}$.

Cadmium sulfate hydrate (purity $98+\%$ ). selenium dioxide (purity $99.8 \%$ ), zinc sulfate heptahydrate (purity $99 \%$ ), sodium sulfate (purity $99+\%$ ) and sulfuric acid (purity $98+\%$ ) were obtained from Aldrich. All chemicals were used as received.

Müller Elektronik-Optik halogen lamp was used as the light source. The light intensity measured on the electrode surface with the Newport 70260 radiant power meter combined with the 70268 probe was $\sim 100 \mathrm{~mW}$ in all the experiments described below. and this value is uncorrected for cell reflection and electrolyte absorption losses. Raman spectra were measured using the $514 \mathrm{~nm}$ line of an $\mathrm{Ar}^{+}$ion laser (HORIBA-LABRAM) at room temperature. Film morphology and atomic composition of the electrodeposited Se and $\mathrm{CdZnSe}$ were studied by energy dispersive X-ray analyses (EDX) attached to a field emission scanning electron microscope (FESEM. JEOL 6700F). Interferometric reflectance spectra were obtained with an Ocean Optics R4000 spectrometer system equipped with a fiber optic probe and a Whalogen light source.

\section{Results and Discussion}

As a prelude to experiments on $\mathrm{CdZnSe}$. the deposition and photoelectrochenical characteristics of selenium (Se) on the Au substrate were studied in detail to complement our earlier studies. ${ }^{89}$ Figure $1 \mathrm{~A}$ contains representative electrochemical. photo-electrochemical. and EQCM data for a polycrystalline Au electrode pre-modified with $\mathrm{Se}$. Se was deposited by holding an Au electrode at $-0.6 \mathrm{~V}$ for $120 \mathrm{~s}$ in 

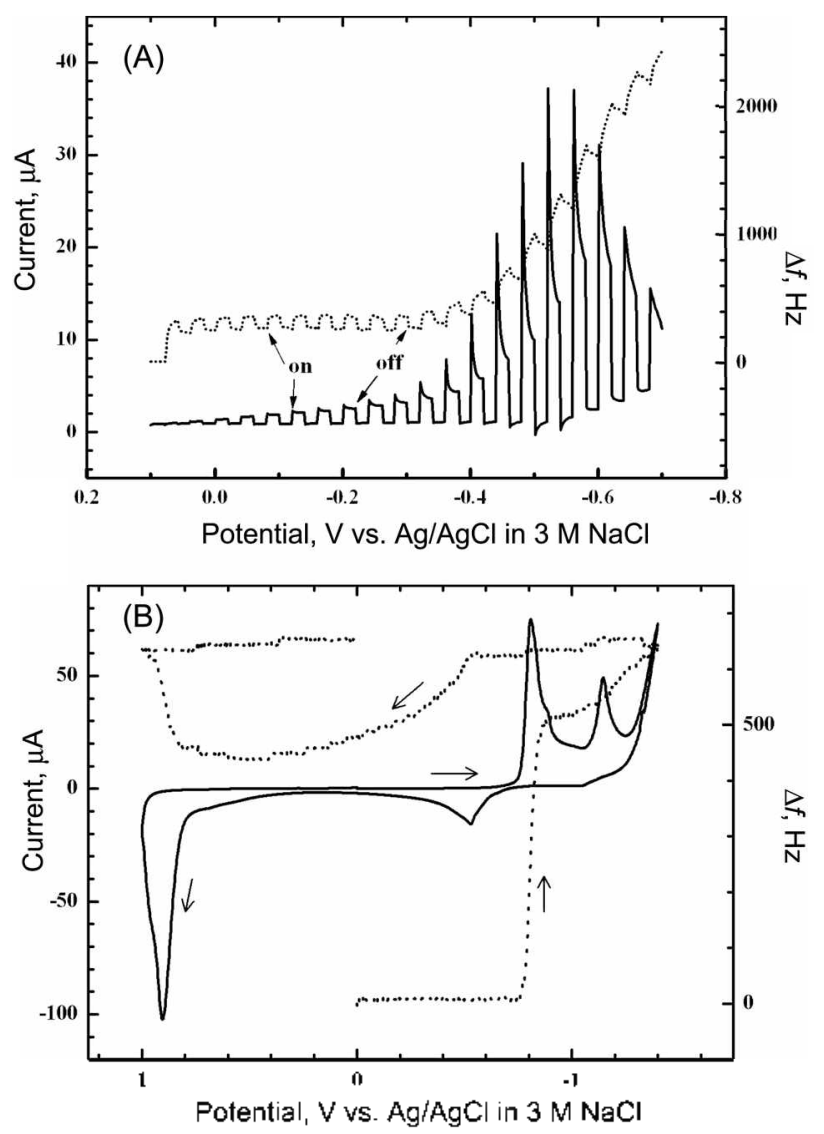

Figure 1. (A) Linear Sweep voltammogram (-) and the corresponding EQCM frequency changes (----) for a Se modified $\mathrm{Au}$ electrode in $0.1 \mathrm{M} \mathrm{Na}_{2} \mathrm{SO}_{4}$. (B) Cyclic voltanmogram (-) and the corresponding EQCM trequency changes (-..-) in the dark for a Se modified $\mathrm{Au}$ electrode in $0.1 \mathrm{M} \mathrm{Na}_{2} \mathrm{SO}_{4}$. Se was deposited by holding a $\mathrm{Au}$ electrode at $-0.6 \mathrm{~V}$ for 120 s in $0.1 \mathrm{M} \mathrm{Na} \mathrm{SO}_{\perp}$ electrolyte containing $10 \mathrm{mM} \mathrm{SeO}$.

$0.1 \mathrm{M} \mathrm{Na}_{2} \mathrm{SO}_{4}$ electrolyte containing $10 \mathrm{mM} \mathrm{SeO}$. The photocurrent transients (solid line) at $-0.25 \mathrm{~V}$ in $0.1 \mathrm{M}$ $\mathrm{Na}_{2} \mathrm{SO}_{4}$ electrolyte are cathodic. signaling that the $\mathrm{Se}$ as deposited on the Au surface is acting as a p-type semiconductor. ${ }^{1 i}$ Apparently, the cathodic photocurrents are accompanied by the photocorrosion of Se to $\mathrm{Se}^{\hat{\imath}}$ which results in mass decreases (EQCM frequency increases. dashed line).

It should be noted that the electrode mass is regained when the light is switched off in each cycle showing that $\mathrm{Se}^{\text {" }}$ redeposits on the Au surface in the dark. To understand this. a combined cyclic voltammogram (CV) and EQCM is obtained for a Se modified $\mathrm{Au}$ electrode in $0.1 \mathrm{M} \mathrm{Na}_{2} \mathrm{SO}_{4}$. As shown in the Figure 1B. cathodic stripping of $\mathrm{Se}^{-} \mathrm{Se}^{\hat{-}-}$ is accompanied by frequency increase (mass decrease) and asgenerated $\mathrm{Se}^{2-}$ species re-deposit on the Au electrode again during the return scan (from $\sim-0.5 \mathrm{~V}$ ). This explains why photogenerated $\mathrm{Se}^{2-}$ is oxidized and re-deposited on the $\mathrm{Au}$ electrode in the dark. Again. frequency increase with an anodic peak at $0.8 \mathrm{~V}$ is due to the oxidation of Se to $\mathrm{Se}^{4-11.12}$

Under the light illunination, electrodeposited $\mathrm{Se}$ is stripped off due to the photocorrosion. ${ }^{11.13}$ Figure 2 contains

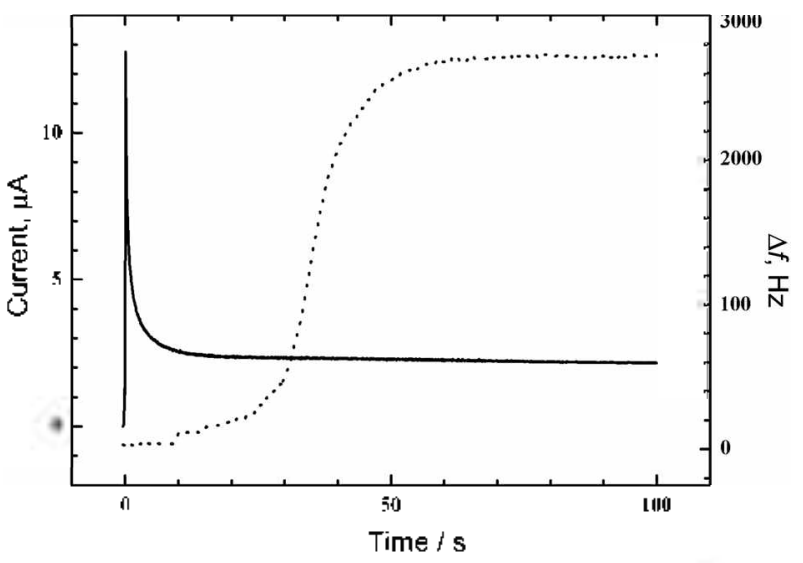

Figure 2. Current flow ( $\longrightarrow$ and coresponding EQCM frequency change (-...) for a Se modified Au electrode in $0.1 \mathrm{M} \mathrm{Na}_{2} \mathrm{SO}_{4}$ at a fixed potential of $-0.25 \mathrm{~V}$ with visible light illumination.

frequency changes during the light illumination on the Se modified Au electrode in $0.1 \mathrm{M} \mathrm{Na}_{2} \mathrm{SO}_{4}$ electrolyte at a fixed potential of $-0.25 \mathrm{~V}$. Again, Se was deposited by holding a Au electrode at $-0.6 \mathrm{~V}$ for $120 \mathrm{~s}$ in $0.1 \mathrm{M} \mathrm{Na}_{2} \mathrm{SO}_{4}$ electrolyte containing $10 \mathrm{mM} \mathrm{SeO}_{2}$. As shown in the figure, frequency increases (mass decrease) due to the photocorrosion of $\mathrm{Se}$ and photocorrosion is completed within $\sim 50 \mathrm{~s}$.

By contrast, addition of $\mathrm{Cd}^{2-}$ and/or $\mathrm{Zn}^{2+}$ to the electrolyte showed different frequency changes during the light illumi-
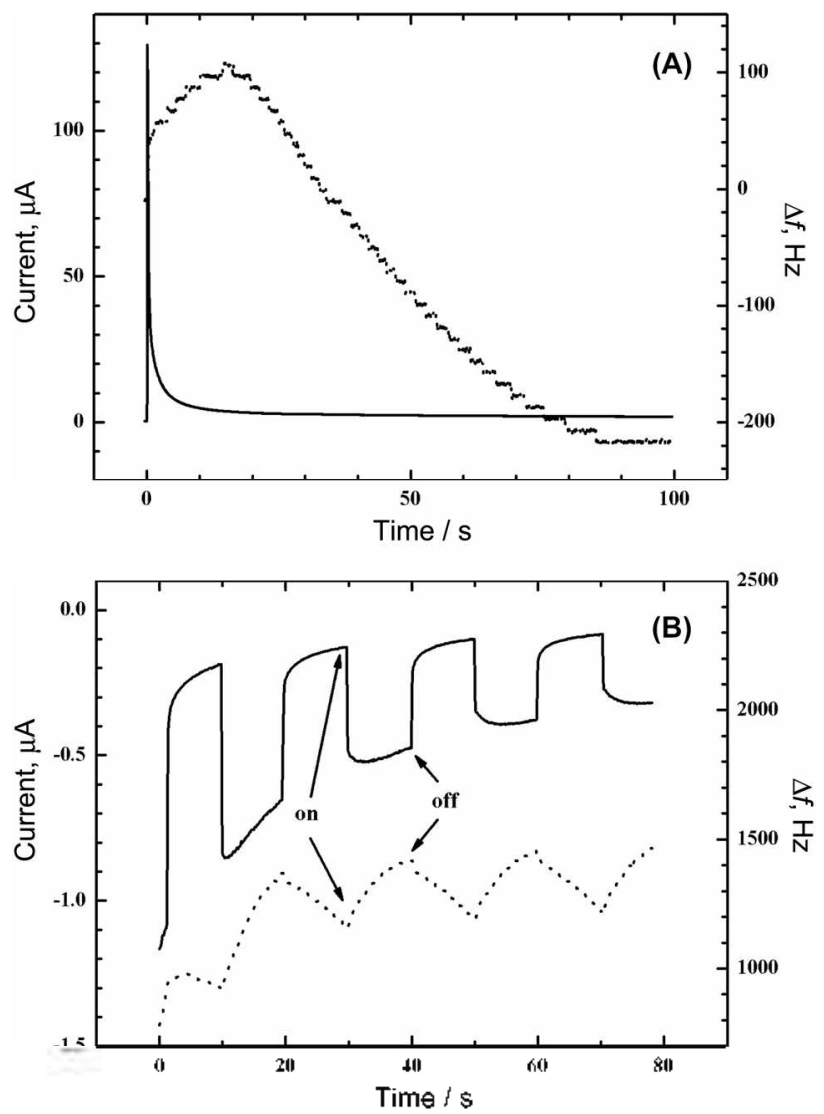

Figure 3. (A) As in figure 2 but with $30 \mathrm{mM} \mathrm{CdSO}_{4}$. (B) Photocurrent transients ( $\longrightarrow$ ) and the corresponding EQCM trequency change (----) for a CdSe modified Au electrode in $0.1 \mathrm{M} \mathrm{Na}_{2} \mathrm{SO}_{4}$ at a ficed potential of $-0.25 \mathrm{~V}$. 

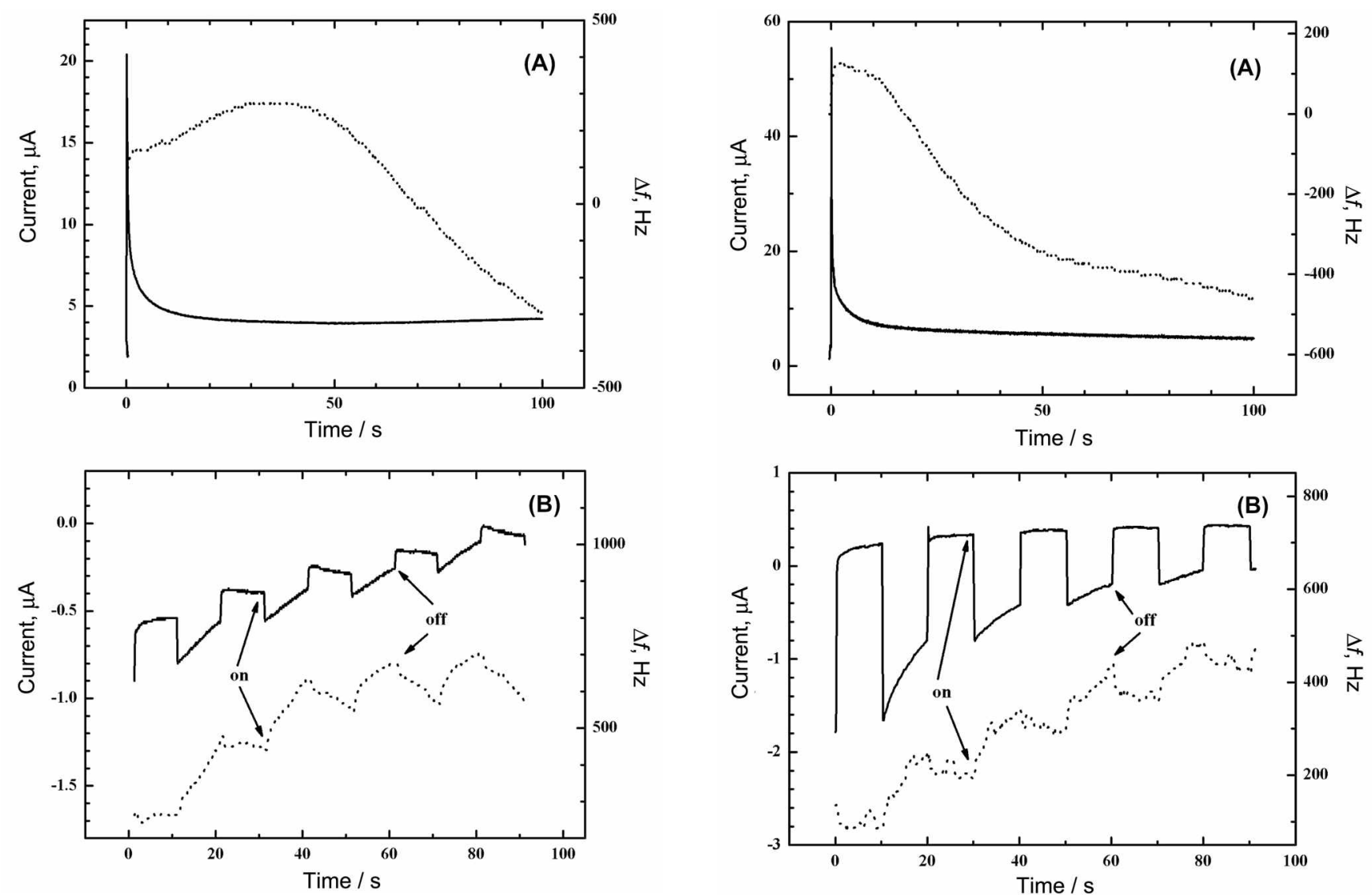

Figure 4. (A) As in tigure 2 but with $50 \mathrm{mM} \mathrm{ZnSO}_{4}$. (B) Photocument transients (-) and the comesponding EQCM frequency change (----) for a ZnSe modified Au electrode in $0.1 \mathrm{M} \mathrm{Na}_{2} \mathrm{SO}_{4}$ at a fixed potential of $-0.25 \mathrm{~V}$.

nation. For example. irradiation on the Se modified $\mathrm{Au}$ electrode in $0.1 \mathrm{M} \mathrm{Na}_{2} \mathrm{SO}_{4}$ electrolyte containing $30 \mathrm{mM}$ $\mathrm{CdSO}_{4}$ at a fixed potential of $-0.25 \mathrm{~V}$ results in frequency increase followed by a frequency decrease (Figure 3A). The frequency decrease resulted from the CdSe formation by the precipitation process:

$$
\mathrm{Cd}^{2+}+\mathrm{Se}^{2-} \text { (by photocorrosion) } \rightarrow \text { CdSe }
$$

Unlike the p-Se, the photocurrent is anodic as shown in figure $3 \mathrm{~B}$ diagnosing that thus formed CdSe is n-type. ${ }^{\mid(i, 1+1+17}$ Again. the frequency changes systemically during the light on-off cycles as explained before (Figure 1A).

When electrolyte contains $\mathrm{Zn}^{2-}$ ions, similar frequency changes are observed during the light illumination on the Se modified Au electrode. Figure $4 \mathrm{~A}$ contains chronoamperometric and EQCM data for the Se modified Au electrode under the light illumination in $0.1 \mathrm{M} \mathrm{Na}_{5} \mathrm{SO}_{4}$ electrolyte containing $50 \mathrm{mM} \mathrm{ZnSO}_{4}$ at a fixed potential of $-0.25 \mathrm{~V}$. The fixed potential of $-0.25 \mathrm{~V}$ was selected since we observed cadmium and zinc deposition at more negative potentials in the dark. In the case of zinc. the frequency increases initially and starts to decrease. which implies the formation of $\mathrm{ZnSe}$. Here the frequency decreases from $\sim 40$ s. which is later than that of the CdSe case. We believe that this is due to the difference in solubility products of CdSe

Figure 5. (A) As in figure 2 but with $1 \mathrm{mM} \mathrm{CdSO}$ and $25 \mathrm{mM}$ $\mathrm{ZnSO}_{4}$. (B) Photocurrent transients (-) and the corresponding EQCM trequency change (-----) for a CdZnSe moditied Au electrode in $0.1 \mathrm{M} \mathrm{Na}_{2} \mathrm{SO}_{4}$ at a fixed potential of $-0.25 \mathrm{~V}$.

$\left(K_{\mathrm{sp}}=4.0 \times 10^{-35}\right)$ and $\mathrm{ZnSe}\left(K_{\mathrm{sp}}=1.0 \times 10^{-27}\right){ }^{18}$ Figure $4 \mathrm{~B}$ shows that $Z$ nSSe formed by photocorrosion of Se and precipitation reaction is n-type since photocurrent is anodic. ${ }^{19}$ It should be mentioned that $\mathrm{CdSe}$ and $\mathrm{ZnSe}$ synthesized from photoelectrodeposition is not stable in $\mathrm{Na}_{2} \mathrm{SO}_{4}$ blank electrolyte. which can be seen from the decay in photocurrent (Figures 3B and $4 \mathrm{~B}$ ). The photocorrosion can be inhibited using a suitable photoelectrolyte (redox couple).

Next. CdZnSe films are sy'nthesized by the same approach described above. When Se modified Au electrode is subjected to photocorrosion in $0.1 \mathrm{M} \mathrm{Na}-\mathrm{SO}_{4}$ electrolyte containing $1 \mathrm{mM} \mathrm{CdSO}$ and $25 \mathrm{mM} \mathrm{ZnSO}_{4}$ at a fixed potential of $-0.25 \mathrm{~V}, \mathrm{CdZnSSe}$ films are synthesized as indicated from frequency decrease (Figure 5A). Also. photoelectrochemical behavior in Figure $5 \mathrm{~B}$ is consistent with ntype behavior for the as-synthesized $\mathrm{CdZnSe}$ films. ${ }^{3}$

It is well known that band gap of $\mathrm{CdZnSe}$ is dependent on the film composition. ${ }^{3 .+}$ The composition of $\mathrm{CdZnSe}$ thin films synthesized by the approach developed here is determined by EDX. Raman spectroscopy and UV reflectance spectroscopy. Figure 6A clearly shows that film composition and therefore band gap can be modulated by controlling electrolyte compositions. As shown in the figure. the ratio of $\mathrm{Zn} / \mathrm{Cd}$ in films increases with the ratio of $\mathrm{Zn} / \mathrm{Cd}$ in electroly'te. In addition. band gap has been modulated by the 

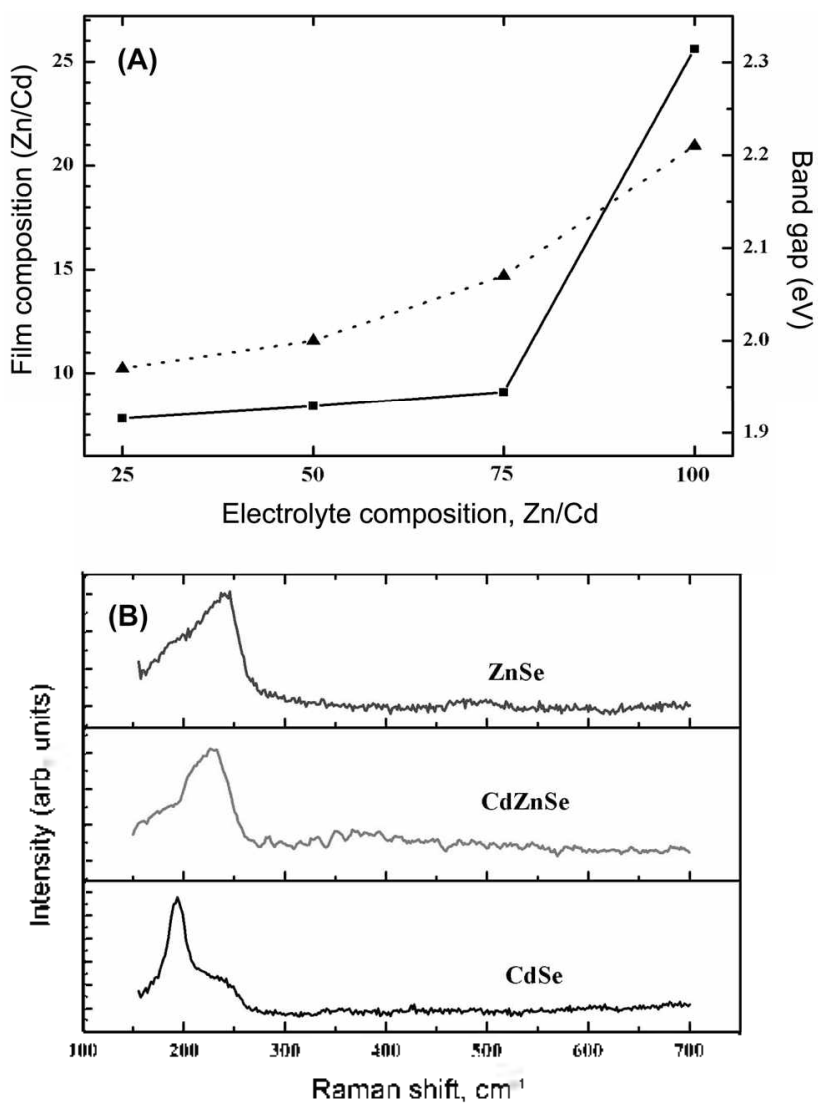

Figure 6. (A) Compositional ( $\longrightarrow$ ) and band gap (-...-) variations of as synthesized CdZnSe films with variations of electrolyte composition. (B) Rannan spectra of CdSe, CdZnSe and ZnSe. CuSe and $\mathrm{ZnSe}$ were synthesized using conditions in figures $3 \mathrm{~A}$ and $4 \mathrm{~A}$, respectively, $\mathrm{CdZ}$ nSe was synthesized using conditions in figure 2 but with $1 \mathrm{mMCdSO}$ and $50 \mathrm{mM} \mathrm{ZnSO}_{4}$.

electrolyte composition. Ranian spectroscopy for as-synthesized films revealed peaks at $200 \mathrm{~cm}^{-1}, 250 \mathrm{~cm}^{-1}$ and 230 $\mathrm{cm}^{-1}$ for $\mathrm{CdSe}{ }^{33} \mathrm{ZnSe} \mathrm{n}^{30.2 \pm 14}$ and $\mathrm{CdZnSe}$.,35 respectively (Figure 6B). Their values are in well agreement with the literature values for these materials.

\section{Conclusion}

We have demonstrated a photoelectrochenical deposition of $\mathrm{CdZnSe}$ thin films using a Se modified $\mathrm{Au}$ electrode using a photocorrosion. Unlike previous studies on binary semiconductors composition and band gap of temary semiconductors have been modulated by controlling composition of electrolytes. Also. we presented a new route for the synthesis of CdSe and $\mathrm{ZnSe}$ films using a photoelectrochemical approach. Finally EQCM combined with amperometry proved to be effective to study photoelectrochemical behavior of binary and ternary semiconductors.
Acknowledgments. This work was supported by a Korea Research Foundation Grant funded by the Korean Government (MOEHRD. Basic Research Promotion Fund) (KRF$2003-015-C 00421)$. S. Han is the recipient of the Seoul Science Fellowship in 2007.

\section{References}

1. (a) Rajeshwar. K. Ade Hater 1992. f, 23 (b) Lee. J: Kim, Y: Kim. K: Huh. Y: Hyun. J: Kim. H. S: Noh. S. J.; Hwang. C. Bull. Korean Chem. Soc, 2007, 28. 1091 .

2. (a) Krishnlan. V: Ham. D.: Mishra. K. K: Rajeshwar. K. J. Electrochent. Soc. 1992. 139. 23. (b) Chae. D.: Seo. K.: Lee. S.: Yootl. S.: Shim. I. Bull. Korean Chent. Soc. 2006. 27. 762.

3. Natarajan, C.: Nogami, G.; Sharon. M. Thin Solid Films 1995. 261. 44 .

4. Chandramohan. R: Mahaligam. T: Chu, J. P.: Sebastian, P. J. Solar Energi Hater: Sola Cells 20(1.81.371.

5. Loglio. F.: Intlocenti. M.: Pezzatini. G: Foresti. M. L. J. Elelctromal. Chem. 2004. 562.117.

6. Kaschner, A: Strassburg, M: Hothimann. A.: Thomsen, C.: Bartels. M.: Lischia, K. Schiliora, D. Appl. Plys. Lett. 2000. 76, 2662.

7. Licht, S. In Semiconductor Electrodes and Photoetectrochemisty Licht. S.. Ed: Wiley: Weinheim. Germany. 2002: Vol. 6. p 325.

8. Hanl. S: Choi. B.: Paeng. K.: Myung. N.: Rajeshwar. K Electrochent Commm. 2007. 9. 1293.

9. Ham. S.: Paeng. K.; Park, J.; Myung, N.; Kim. S.: Rajeshwar, K 1. Appl Electrochen 2008. 38, 203.

10. Myung. N.: de Taccon, N.: Rajeshwar, K. Electrochem. Commun. 1999. 1,42

11. Rabchyıski. S. M.: Iranou. D. K.: Streltsov. E. A. Electrochent. Contmim 2004. 6. 1051 .

12. Myung. N.: Wei. C.: Rajeshwar. K. And. Chem. 1992. 6+. 2701.

13. Streltsov. E. A.; Poznyak, S. K.: Usipovich. N. P. d. Eletchoanal. Chen $2002,518,103$.

14. Lade. S. J.: Uplane. M. D.; Lokhande. C. D. Aater: Chem. Phus. 2001. 69.36

15. Kazacos. M. S.: Miller. B. J. Electrochen. Soc. 1980. 127. 2378.

16. Rajeshwar. K:: Thompson. L:: Singh. P.: Kainthla. R. C.: Chopra. K. L.J. Electrochen. Soc. 1981, 128. 1744.

17. Choi, S.: Woo, D.: Myung, N.: Kang, H.: Park. S. J. Electrochem. Soc, 2001, 1+8, C 569.

18. Hodes. G. Chentical Solution Deposition of Semiconductor Films: Marcel Dekker: New York. U.S.A.. 2003: p 5.

19. Riveros. G.: Gumez. H.: Henriquez. R.: Schrebler. R.: Marotti. R. E: Dalchiele. E. A. Solo Energy 1 1ater Sola Cells 2001, 70. 255.

20. Mahalingam. T.: Kathalingam. A.: Velumani, S.: Lee, S.: Sun, M. H.: Deak. K. Y. J. Mater. Sci. 20k6. H. 3353.

21. Murali. K. R.: Balasubramaniant. M. Hater. Sci. Engr. A 2006. +31. 118.

22. Kumaresan. R: Ichimura, M: Arai. E. Thin Solid Films 2002. H1.25.

23. Desnica-Frankovic. I. D.: Dubcek. P. Buljan. M.: Furic, K: Destnica. U. V: Bernstorff. S.: Karl. H.: Großhans. I.: Stritzker. B. Nucl. Whst and Heth. B 2005. 238. 302.

24. Lu. G.: An. H: Chen. Y.: Huang. T.: Zhang. H: Xiang. B.: Zhao. Q: Yu. D.: Du. W. J. Crystal Growth 2005, 274. 530.

25. Schreder. B.: Matemy. A.: Kiefer, W.: Kummell, T.: Bacher, G: Forchel. A.: Landwehr. G. Solid State Chem. 2000. 114. 435. 